\title{
The Legal Prohibition of Surrogacy for Muslims in Malaysia: A Critical Analysis
}

\section{Kyaw Hla Win @ Md. Hassan Ahmed}

Senior Lecturer, School of Law (SOL)

UUM College of Law, Government and International Studies (UUM COLGIS)

Universiti Utara Malaysia (UUM)

\begin{abstract}
This paper sets out to determine the legal status of human reproductive surrogacy for Muslims in Malaysia. It asks whether or not Muslims are prohibited by Islamic Law from human reproductive surrogacy. Muslims are governed in their personal matters by the Islamic law of the respective states. The word Muslim is not defined in the Malaysian Constitution. Argument deals with the position of the Islamic law in Malaysia, before discussing surrogacy. This will be set out first in the position of the Islamic law, then, argument discusses the role of the Islamic jurist and the Islamic legal consultative committee. This is followed by the role of the national fatwa committee. Finally, the article deals with the prohibition of surrogacy for Muslims as a legal dilemma. The paper will suggest that in some states, Muslims would be free to use surrogacy services in accordance with the general law of Malaysia.
\end{abstract}

Keywords: Surrogacy, Surrogate mother, Surrogacy in Malaysia, Surrogacy in Islam.

\section{Introduction}

This paper sets out to determine the legal status of human reproductive surrogacy for Muslims living in the Federation of Malaysia. It asks whether or not Muslim people are prohibited expressly by the Islamic Law from engaging in human reproductive surrogacy.

The Federation of Malaysia has thirteen States. They are Johore, Kedah, Kelantan, Malacca, Negeri Sembilan, Pahang, Penang, Perak, Perlis, Sabah, Sarawak, Selangor, Terengganu, and the Federal Territories which consists of the Federal Territory of Kuala Lumpur, the Federal Territory of Putrajaya and the Federal Territory of Labuan. Therefore, it can be said that there are fourteen provinces (thirteen States and the Federal Territories) in the Federation of Malaysia. ${ }^{1}$

In the Malaysian legal context, Muslims are governed in their personal matters by the Islamic law of the respective provinces. The word "Muslim" is not defined anywhere in the Malaysian Federal Constitution. Nonetheless, who should be called a "Muslim" is described under section 2 of the Administration of Islamic Law (Federal Territories) Act 1993 as follows:

(a) a person who professes the religion of Islam;

(b) a person either or both of whose parents were, at the time of the person's birth, Muslims;

(c) a person whose upbringing was conducted on the basis that he was a Muslim;

(d) a person who has converted to Islam;

(e) a person who is commonly reputed to be a Muslim; or

\footnotetext{
${ }^{1}$ Article 1 of the Federal Constitution 1957.
} 
(f) a person who is shown to have stated, in circumstances in which he was bound by law to state the truth, that he was a Muslim, whether the statement be verbal or written. ${ }^{2}$

First, argument deals with the position of the religion of Islam and the Islamic law in Malaysia, before discussing the subject matter of surrogacy. This will be set out in position of the Islamic law, then, argument discusses the role of the islamic jurist and the islamic legal consultative committee. This will be followed by analysis of the role of the national fatwa committee. Finally, the article will deal with the prohibition of surrogacy for Muslims as it might represent a legal dilemma.

The paper will suggest that in some states in these states, Muslims would be free to use surrogacy services in accordance with the general law of Malaysia.

\section{The Legal Position In The Religion of Islam In Malaysia}

The Federal Constitution states that Islam is the religion of the Federation and other religions are also allowed to be practised in peace and harmony in any part of the Federation. ${ }^{3}$ It further guarantees the right of every religious group to manage its own religious affairs; establish and maintain institutions for religious or charitable purposes; and acquire and own property and hold and administer it in accordance with law. ${ }^{4}$ Despite the fact that the Federal Constitution makes Islam the religion of the Federation, it does not include Islamic law as one of the branches of law under its definition of law. It defines law as including written law, the common law in so far as it is in operation in any part or in the whole of the Federation, and any custom or usage having the force of law in any part or the whole of the Federation. ${ }^{5}$ There is no head of the Islamic religion designated for the federation as a whole. There are only nine states with their own rulers. They are Johore, Kedah, Kelantan, Negeri Sembilan, Pahang, Perak, Perlis, Selangor and Terengganu. Every state which has a ruler of its own regards its ruler as the head of the religion of Islam, within the state, in accordance with the Constitution of that State. However, when the Conference of Rulers agrees to extend any religious acts, observances or ceremonies to the Federation as a whole, each of the other rulers, in his capacity of head of the religion of Islam, authorises the Yang di-Pertuan Agong (Supreme Head of the Federation) to represent him. ${ }^{6}$

The Yang di-Pertuan Agong is the Supreme Head of the Federation, taking precedence over all other persons in the Federation. ${ }^{7}$ One out of the nine Rulers is elected routinely as the Yang di-Pertuan Agong by the Majlis Raja-Raja (Conference of Rulers) for a term of five years. ${ }^{8}$ The Conference of Rulers is established by virtue of Article 38 of the Federal Constitution 1957. It consists of nine of their Royal Highnesses the Rulers and four Heads of State (Yang di-Pertua Negeri) for four States not having a Ruler of their own. These four states are Penang, Malacca, Sabah and Sarawak. ${ }^{9}$ However, participation of these four Heads of States in the Conference of Rulers is very limited and they are not members in any proceeding relating to the election or removal of the Yang di-Pertuan Agong or the election of the Timbalan Yang diPertuan Agong ${ }^{10}$ (Deputy Supreme Head of the Federation). Neither do they participate in any proceedings relating solely to the privileges, position, honours and dignities of their Royal Highnesses or to religious acts, observances or ceremonies. ${ }^{11}$ The Federation Constitution states as follows.

(1) There shall be a Deputy Supreme Head of the Federation (to be called the Timbalan Yang di-Pertuan Agong) who shall exercise the functions and have the privileges of the Yang di-Pertuan Agong during any vacancy in the office of the Yang di-Pertuan Agong and

\footnotetext{
${ }^{2}$ Section 2 of the Administration of Islamic Law (Federal Territories) Act 1993.

${ }^{3}$ Article 3 (1) of the Federation Constitution 1957.

${ }^{4}$ Article 11 (3) of the Federation Constitution 1957.

${ }^{5}$ Article 160 of the Federation Constitution 1957.

${ }^{6}$ Article 3 (2) of the Federation Constitution 1957.

${ }^{7}$ Article 32 (1) of the Federation Constitution 1957.

${ }^{8}$ Article 32 (3) of the Federation Constitution 1957.

${ }^{9}$ Item 1 of the Fifth Schedule of the Federal Constitution 1957.

${ }^{10}$ The Federation Constitution 1957, Article 33.

${ }^{11}$ Item 7 of the Fifth Schedule of the Federal Constitution 1957.
} 
during any period during which the Yang di-Pertuan Agong is unable to exercise the functions of his office owing to illness, absence from the Federation or for any other cause, but the Timbalan Yang di-Pertuan Agong shall not exercise those functions during any inability or absence of the Yang di- Pertuan Agong which is expected to be less than fifteen days, unless the Timbalan Yang di-Pertuan Agong is satisfied that it is necessary or expedient to exercise such functions.

(2) The Timbalan Yang di-Pertuan Agong shall be elected by the Conference of Rulers for a term of five years, or if elected during the term for which the Yang di-Pertuan Agong was elected, for the remainder of that term, but may at any time resign his office by writing under his hand addressed to the Conference of Rulers and shall cease to hold office on ceasing to be a Ruler. ${ }^{12}$

One of the functions of the Conference of Rulers, as spelled out under Article 38 of the Federation Constitution, is that it has the power to agree or disagree in the extension of any religious acts, observances or ceremonies to the Federation as a whole. ${ }^{13}$ In their own discretion, any members of the Conference of Rulers may decide in any proceeding relating to the agreeing or disagreeing to the extension of any religious acts, observances or ceremonies to the whole Federation. ${ }^{14}$ The Conference of Rulers shall take its decision by a majority of the members voting in any case where the Conference of Rulers is not unanimous. $^{15}$

The Federation Constitution imposes a provision to confer on the Yang di-Pertuan Agong the position of head of the religion of Islam in the Constitutions of the States of Malacca, Penang, Sabah and Sarawak. ${ }^{16}$ This is because these states do not have their own Rulers. Moreover, the Federal Constitution makes the Yang di-Pertuan Agong the head of the religion of Islam in the Federal Territories of Kuala Lumpur, Labuan and Putrajaya. ${ }^{17}$ Apart from being the head of the religion of Islam, the Yang di-Pertuan Agong has no power to exercise his functions as ruler in any other capacities, even in his own State. ${ }^{18}$

\section{The Position Of The Islamic Law}

The power to determine and enforce Islamic law is vested to the State concerned under the Federal Constitution 1957. ${ }^{19}$ The first item of the state legislative list confers the power to determine Islamic law as well as constitute, organise and stipulate procedure of Syariah courts to the thirteen States. The Federal Parliament is also vested the similar power for the same purpose in the Federal Territories of Kuala Lumpur, Labuan and Putrajaya. ${ }^{20}$ The Federal Constitution further gives the power to the Parliament to make provisions for regulating Islamic religious affairs and to constitute a Council to advise the Yang diPertuan Agong in matters relating to the religion of Islam. ${ }^{21}$ The government and administration of the Federal Territories of Kuala Lumpur, Labuan and Putrajaya include Islamic law therein, to the same extent as provided in the Item I of the State List. ${ }^{22}$

Accordingly, the Federal Parliament and the thirteen state legislative assemblies have the power to determine Islamic law relating to personal matters, including succession, testate and intestate, betrothal,

\footnotetext{
${ }^{12}$ The Federation Constitution 1957, Article 33:

${ }^{13}$ Article 38 (2) (b) of the Federation Constitution 1957.

${ }^{14}$ Article 38 (6) (d) of the Federation Constitution 1957.

${ }^{15}$ Item 8 of the Fifth Schedule of the Federal Constitution 1957.

${ }^{16}$ Article 3 (3) of the Federation Constitution 1957.

${ }^{17}$ Article 3 (5) of the Federation Constitution 1957.

${ }^{18}$ Article 34 (1) of the Federation Constitution 1957.

${ }^{19}$ See also KH Win@MH Ahmed, 'Law: Functions, Classifications and Divisions', in AAA Mohamad (ed.), Malaysian Legal System, The Malaysian Current Law Journal Sdn Bhd, 2014, pp. 36-37; WA Hamzah, A First Look at the Malaysian Legal System, Oxford Fajar Sdn Bhd, 2009, pp. 115-149; WM Aun, The Malaysian Legal System, 3rd edn, Pearson Malaysia Sdn Bhd, 2005, pp. 174-211.

${ }^{20}$ Item 1, List II - State List, Ninth Schedule of the Federal Constitution 1957.

${ }^{21}$ Article 3 (5) of the Federation Constitution 1957.

${ }^{22}$ Item 6 (e), List I - Federal List, Ninth Schedule of the Federal Constitution 1957.
} 
marriage, divorce, dower, maintenance, adoption, legitimacy, guardianship, gifts and partitions. The Federal Constitution provides that Syariah courts have jurisdiction only over persons professing the religion of Islam in respect only of any of their personal matters. ${ }^{23}$ Since it would be a very large scope of research to discuss the position of Islamic law in each of the fourteen provinces of Malaysia, discussion will be based predominantly on the position of Islamic law in the Federal Territories, as a model for the other parts of the Federation.

\section{The Role of the Islamic Jurist and the Islamic Legal Consultative Committee}

Despite the fact that the Yang di-Pertuan Agong and the rulers are the heads of the religion of Islam in their respective provinces, they may not have sufficient skills and expertise in determining what exactly would be a correct legal ruling under Islamic law, in various contemporary issues. Thus, they usually appoint any fit and proper person to be the Mufti (Islamic jurist) and the Deputy Mufti (Deputy Islamic jurist), on the advice of the Minister, ${ }^{24}$ after due consultation with the Islamic Religious Council. ${ }^{25}$ Such a duly appointed Islamic jurist has to assist and advise the Ruler in respect of all matters of Islamic Law. ${ }^{26}$ There are in total fourteen Islamic jurists to represent each of the thirteen States and the Federal Territories in Malaysia.

The duly appointed Islamic jurist may make a fatwa (Islamic legal ruling) on any unsettled or controversial question relating to Islamic law and publish in the Gazette on the direction of the ruler, on his own initiative or on the request of any person made by letter addressed to him. ${ }^{27}$

The Islamic jurist, before proposing any Islamic legal ruling, may conduct studies or research as the case may be for the purpose of preparing a working paper. ${ }^{28}$ Although there are four prevalent schools of thought (i.e., Maliki, Hanafi, Syafie and Hanbali) in deducing legal rulings from the primary and secondary sources of Islamic law, the duly appointed Islamic jurist ordinarily has to follow the views accepted by the Syafie school of thought in issuing any Islamic legal ruling. ${ }^{29}$ The Islamic jurist may follow other schools of thought (i.e., Maliki, Hanafi and Hanbali) if he considers that following the Syafie school of thought will

\footnotetext{
${ }^{23}$ Item 1, List II - State List, Ninth Schedule of the Federal Constitution 1957.

${ }^{24}$ Section 2 of the Administration of Islamic Law (Federal Territories) Act 1993: "Minister" means the Minister charged with responsibility for the administration of the religion of Islam in the Federal Territories.

${ }^{25}$ The Islamic Religious Council of the Federal Territories is established under section 4 (1) of the Administration of Islamic Law (Federal Territories) Act 1993 which provides: "There shall be a body to be known as the "Majlis Agama Islam Wilayah Persekutuan" to advise the Yang di-Pertuan Agong in matters relating to the religion of Islam". Section 10 (1) of the Administration of Islamic Law (Federal Territories) Act 1993 which enumerates members of the Islamic Religious Council of the Federal Territories as follows: "(a) a Chairman;

(b) a Deputy Chairman;

(c) the Chief Secretary to the Government or his representative;

(d) the Attorney General or his representative;

(e) the Inspector-General of Police or his representative;

(f) the Mufti;

(g) the Commissioner of the City of Kuala Lumpur; and

(h) fifteen other members, at least five of whom shall be persons learned in Islamic studies".

In addition, section 13 of the Administration of Islamic Law (Federal Territories) Act 1993 requires all appointments and revocations of appointment under sections 10 shall be published in the Gazette. The primary task of the Islamic Religious Council of the Federal Territories is to assist and advise the Yang diPertuan Agong in respect of all matters relating to the religion of Islam within the Federal Territories except matters of Islamic Law and those relating to the administration of justice. In all other matters, it is the chief authority in the Federal Territories after the Yang di-Pertuan Agong. See section 31 of the Administration of Islamic Law (Federal Territories) Act 1993; Section 32 (1) of the Administration of Islamic Law (Federal Territories) Act 1993.

${ }^{26}$ Section 33 of the Administration of Islamic Law (Federal Territories) Act 1993.

${ }^{27}$ Section 34 (1) of the Administration of Islamic Law (Federal Territories) Act 1993.

${ }^{28}$ Section 37 (6) of the Administration of Islamic Law (Federal Territories) Act 1993.

${ }^{29}$ Section 39 (1) of the Administration of Islamic Law (Federal Territories) Act 1993.
} 
lead to a situation which is repugnant to public interest. ${ }^{30}$ In a situation where he considers that it is impossible to follow any of or all four schools of thought without leading to a situation which is repugnant to public interest, he may then resolve the question according to his own judgment without being bound by any of or all four schools of thought. ${ }^{31}$

Afterwards, Islamic jurist has to call a meeting of the Islamic Legal Consultative Committee in order to discuss the proposed Islamic legal ruling. ${ }^{32}$ The Islamic Legal Consultative Committee consists of the following members:

the Mufti (Chairman);

$$
\text { the Deputy Mufti; }
$$

(c) two members of the Islamic Religious Council;

(d) not less than two fit and proper persons to be appointed by the Islamic Religious Council; and

(e) an officer of the Islamic Religious Department of the Federal Territories to be appointed by the Islamic Religious Council, who shall be the Secretary. ${ }^{33}$

Until and unless it is published in the Gazette, no statement made by an Islamic jurist can be considered as an Islamic legal ruling per se. ${ }^{34}$ Once it is published, the Islamic legal ruling is binding upon every Muslim residing in the respective State as his religious duty to uphold it and abide by it. ${ }^{35}$ An Islamic legal ruling is recognised by all Syariah Courts ${ }^{36}$ in the respective State as authoritative of all matters laid down therein. ${ }^{37}$ The Islamic jurist may amend, modify or revoke any Islamic legal ruling that has been issued previously by him or any of his predecessors.

The administration of justice relating to personal matters among persons professing the religion of Islam is vested to the various tiers of Syariah Courts in the Federal Territories. Under section 40 of the Administration of Islamic Law (Federal Territories) Act 1993, the Yang di-Pertuan Agong constitutes the Syariah Subordinate Court, the Syariah High Court and the Syariah Appeal Court for the Federal Territories on the advice of the Minister by notification in the Gazette. The Yang di-Pertuan Agong appoints a Chief Syariah Judge, Judges of the Syariah Appeal Court and Judges of the Syariah High Court on the advice of the Minister after the consultation with the Islamic Religious Council in accordance with sections 41 (1), 42 (1) and 43 (1) of the Administration of Islamic Law (Federal Territories) Act 1993. Besides, the Yang diPertuan Agong also appoints Judges of the Syariah Subordinate Courts on the recommendation of the Chief Syariah Judge under section 44 (1) of the Administration of Islamic Law (Federal Territories) Act 1993. All the appointments of the respective judges must be published in the Gazette as it required under sections 41 (4), 42 (2), 43 (3) and 44 (2) of the Administration of Islamic Law (Federal Territories) Act 1993. In its civil jurisdiction, the Syariah Courts hear and determine all actions and proceedings in which all the parties are Muslims and which relate to personal matters such as betrothal, marriage, reconciliation, divorce, nullity of marriage, judicial separation, maintenance of dependants, legitimacy of children, guardianship of infants, custody of infants, separation of matrimonial property, any other matters relating to the relationship between husband and wife, division and inheritance of testate or intestate property, wills or death-bed gifts

\footnotetext{
${ }^{30}$ Section 39 (2) of the Administration of Islamic Law (Federal Territories) Act 1993.

${ }^{31}$ Section 39 (3) of the Administration of Islamic Law (Federal Territories) Act 1993.

${ }^{32}$ Section 37 (5) of the Administration of Islamic Law (Federal Territories) Act 1993.

${ }^{33}$ Section 37 (2) of the Administration of Islamic Law (Federal Territories) Act 1993.

${ }^{34}$ Section 34 (2) of the Administration of Islamic Law (Federal Territories) Act 1993.

${ }^{35}$ Section 34 (3) of the Administration of Islamic Law (Federal Territories) Act 1993.

${ }^{36}$ See section 46 (2) (b) of the Administration of Islamic Law (Federal Territories) Act 1993.

${ }^{37}$ Section 34 (4) of the Administration of Islamic Law (Federal Territories) Act 1993.

${ }^{38}$ Section 36 (1) of the Administration of Islamic Law (Federal Territories) Act 1993.
} 
of a deceased Muslim, determination of the persons entitled to share in the estate of a deceased Muslim and the shares to which such persons are respectively entitled, among others. ${ }^{39}$

\section{The Role of the National Fatwa Committee}

Accordingly, it is a reasonable proposition that the administration of Islamic law in Malaysia may vary from state to state. Therefore, in 1968, the National Council for Islamic Religious Affairs Malaysia was established by the Conference of Rulers with the intention of promoting unification and harmonisation of the administration of Islamic law among the fourteen provinces of the Federation. The National Council for Fatwa Committee of Islamic Religious Affairs Malaysia (also known as the "National Fatwa Committee") ${ }^{40}$ was established in early 1970 under Article 11 of the Rules of the National Council for Islamic Religious Affairs Malaysia. It comprises the Islamic jurists of all States and five other experts on Islamic law appointed by the Yang di-Pertuan Agong. The primary task of the National Fatwa Committee is to consider, decide and issue an Islamic legal ruling on any matter pertaining to Islam as referred to it by the Conference of Rulers.

However, from the legal point of view, an Islamic legal ruling issued by the National Fatwa Committee does not have the binding force of law unless it is published in the Gazette of the respective State. Nonetheless, in normal practice, an Islamic legal ruling issued by the National Fatwa Committee will be channeled to the State authority for the publication in the Gazette. ${ }^{41}$ This is mainly because it issues an Islamic legal ruling to the satisfaction of all Islamic jurists duly appointed by all provinces across the nation.

\section{The Prohibition Of Surrogacy for Muslims: A Legal Dilemma}

Since 2003, the National Fatwa Committee had discussed various issues relating to human fertilisation with the assistance of modern technologies and subsequently decided several Islamic legal rulings to that effect. It started the discussion on the validity of in vitro fertilisation as an effort to have baby in Islam at its $55^{\text {th }}$ Conference held on $8^{\text {th }}$ April 2003 and decided that "[T] ransferring fertilised egg (zygote) into the wife's uterus after the death of the husband or after divorce is forbidden". ${ }^{2}$ Again, at its $56^{\text {th }}$ Conference held on $7^{\text {th }}$ May 2003, it stressed the issue of mixing eggs. It prohibited the mixing process conducted with eggs which were extracted before the solemnisation of marriage. Nevertheless, it approved such process with eggs that were extracted during the marital period, but only between the married couple. ${ }^{43}$

With regard to surrogacy, the National Fatwa Committee emphasised its ruling of obtaining the service of surrogate mother to have a child, at its $80^{\text {th }}$ Conference, held on $1^{\text {st }}-3^{\text {rd }}$ February 2008. It decided that surrogacy was forbidden in Islam, even if the sperm and ovum were taken from a legally married couple, as it caused genetic confusion to the unborn baby. It acknowledged that the development of modern medical technologies greatly contributed in the field of human fertility and reproduction. At the same time, it was also aware of the issue of uncertainty in lineage of a baby conceived by a surrogate mother. In Islam, lineage is one of the most essential matters whose propriety must be safe-guarded in society. Besides, the

\footnotetext{
${ }^{39}$ See section 46 (2) (b) of the Administration of Islamic Law (Federal Territories) Act 1993.

${ }^{40}$ Hereinafter referred to as "the National Fatwa Committee".

${ }^{41}$ Department of Islamic Development Malaysia, What is Fatwa?, Fatwa Management Division, 2015, retrieved 16 April 2015, <http://www.e-fatwa.gov.my/apa-itu-fatwa>.

${ }^{42}$ Department of Islamic Development Malaysia, In vitro fertilization as an effort to have baby, Fatwa Management Division, 8 April 2003, retrieved 16 April 2015, <http://www.e-fatwa.gov.my/fatwakebangsaan/pencantuman-benih-untuk-mendapatkan-zuriat-0>.

${ }^{43}$ Department of Islamic Development Malaysia, In vitro fertilization as an effort to have baby 2, Fatwa Management Division, 7 May 2003, retrieved 16 April 2015, <http://www.e-fatwa.gov.my/fatwakebangsaan/pencantuman-benih-untuk-mendapatkan-zuriat-2>.
} 
baby would only have a genetic relationship with the surrogate mother, without a blood relationship, whereby it could cause confusion in kinship and descent. ${ }^{44}$

As discussed above, such a decision duly made by the National Fatwa Committee must be published in the Gazette of each State concerned in order to render binding legal effect among its Muslim subjects. In the Federal Territories of Kuala Lumpur, Putrajaya and Labuan, the Islamic legal ruling on prohibition of the use of surrogate mother to have a child was decided by the National Fatwa Committee. It had been given legal effect by publishing it in the Federal Gazette on 10 July $2008 .{ }^{45}$ Similarly, on 24 December 2010 , the Fatwa Committee of the State of Selangor, on the direction of the ruler, published the Islamic legal ruling on the issue of surrogacy in its Gazette. It states that using the service of a surrogate mother to get a child is forbidden by Islam, even when sperm and ovum are taken from a married couple, because it would cause confusion of lineage of the yet-to-be-born child. ${ }^{46}$

In some States, the validity of surrogacy in Islam was thoroughly discussed by the respective entities responsible for the issuance of Islamic legal rulings. They reached the same conclusions as the National Fatwa Committee. The State of Pahang Consultative Committee of the Islamic Law discussed the issue of surrogacy, in a meeting convened on 11-12 June 2008, and decided that using the service of a surrogate mother was illegal, even if the sperm and ovum were taken from the legitimate couple. This was because it would cause confusion in the blood kinship of the child. It further prohibited the donation of sperm, ovum, embryo and uterus by a third party or use of other methods in order to have a child. ${ }^{47}$ Similarly, on 4 July 2013, the Board of Fatwa of the State of Sarawak decided that using the service of a surrogate mother to have a child was forbidden by Islam, even if sperm and ovum were taken from a married couple. This was because it would cause confusion of the lineage of the child to be born. ${ }^{48}$ To confuse matters further, both of these States have not published the said Islamic legal rulings in their respective Gazettes, to date.

Generally, it can be said that the use of a surrogate mother to have a baby is prohibited for Muslims in Malaysia. Nevertheless, the prohibition will only have a binding legal effect upon people professing the religion of Islam in states which have already gazetted such a legal ruling. Conversely, legally and technically, Muslims in States that have not yet gazetted their prohibition retain the option as to whether or not to observe the rule.

\section{Conclusion}

The Government Gazettes in Malaysia make it unclear as to whether Muslim Malaysian are bound by prohibitions against human reproductive surrogacy. In any event, it appears that some states have not gazetted the Islamic prohibition. Arguably, in these states, Muslims would be free to use surrogacy services in accordance with the general law.

\footnotetext{
${ }^{44}$ Department of Islamic Development Malaysia, The ruling on the use of surrogate mother to have a child, Fatwa Management Division, 1 - 3 February 2008, retrieved 16 April 2015, <http://www.efatwa.gov.my/fatwa-kebangsaan/hukum-menggunakan-kaedah-khidmat-ibu-tumpang-untuk-mendapatkanzuriat>.

${ }^{45}$ Department of Islamic Development Malaysia, The ruling on the use of surrogate mother to have a child, Fatwa Management Division, 10 July 2008, retrieved 16 April 2015, <http:/www.e-fatwa.gov.my/fatwanegeri/hukum-menggunakan-kaedah-khidmat-ibu-tumpang-untuk-mendapatkan-zuriat>.

${ }^{46}$ Government of Selangor, Hukum Menggunakan Kaedah Khidmat Ibu Tumpang (Surrogate Motherhood) Untuk Mendapatkan Zuriat, Gazette No. 1, Reference No. MAIS/SU/BUU/02/016/2-1; P.U. Sel. AGM. 0007. Jld. 2, 6 February 2011, retrieved 17 April 2015,

$<$ http://jawatankuasafatwakumpulan7tlc4.yolasite.com/resources/PewartaanFatwa2011(3).pdf>.

${ }^{47}$ Department of Islamic Development Malaysia, Hukum Menggunakan Kaedah Khidmat Ibu Tumpang Untuk Mendapatkan Zuriat, Fatwa Management Division, 11 - 12 June 2008, retrieved 17 April 2015, $<$ http://www.e-fatwa.gov.my/fatwa-negeri/hukum-menggunakan-kaedah-khidmat-ibu-tumpang-untukmendapatkan-zuriat-0>.

${ }^{48}$ Department of Islamic Development Malaysia, Hukum Menggunakan Kaedah Khidmat Ibu Tumpang (Surrogate Motherhood) Untuk Mendapatkan Zuriat, Fatwa Management Division, 4 July 2013, retrieved 17 April 2015, <http:/www.e-fatwa.gov.my/fatwa-negeri/hukum-menggunakan-kaedah-khidmat-ibutumpang-surrogate-motherhood-untuk-mendapatkan-z-0>.
} 
M. Hassan Ahmed, 'The Legal Prohibition of Surrogacy for Muslims in Malaysia: A Critical Analysis', UUMJLS, vol. 6, no. 1, 2015, pp. 033-040.

\section{Bibliography}

[1] Department of Islamic Development Malaysia, Hukum Menggunakan Kaedah Khidmat Ibu Tumpang Untuk Mendapatkan Zuriat, Fatwa Management Division, 11 - 12 June 2008, retrieved 17 April 2015, <http://www.e-fatwa.gov.my/fatwa-negeri/hukum-menggunakan-kaedah-khidmat-ibu-tumpanguntuk-mendapatkan-zuriat-0>.

[2] Department of Islamic Development Malaysia, Hukum Menggunakan Kaedah Khidmat Ibu Tumpang (Surrogate Motherhood) Untuk Mendapatkan Zuriat, Fatwa Management Division, 4 July 2013, retrieved 17 April 2015, <http://www.e-fatwa.gov.my/fatwa-negeri/hukum-menggunakan-kaedah-khidmatibu-tumpang-surrogate-motherhood-untuk-mendapatkan-z-0>.

[3] Department of Islamic Development Malaysia, In vitro fertilization as an effort to have baby, Fatwa Management Division, 8 April 2003, retrieved 16 April 2015, <http://www.e-fatwa.gov.my/fatwakebangsaan/pencantuman-benih-untuk-mendapatkan-zuriat-0>.

[4] Department of Islamic Development Malaysia, In vitro fertilization as an effort to have baby 2, Fatwa Management Division, 7 May 2003, retrieved 16 April 2015, <http://www.e-fatwa.gov.my/fatwakebangsaan/pencantuman-benih-untuk-mendapatkan-zuriat-2>.

[5] Department of Islamic Development Malaysia, The ruling on the use of surrogate mother to have a child, Fatwa Management Division, 1 - 3 February 2008, retrieved 16 April 2015,

$<$ http://www.e-fatwa.gov.my/fatwa-kebangsaan/hukum-menggunakan-kaedah-khidmat-ibu-tumpang-untukmendapatkan-zuriat>.

[6] Department of Islamic Development Malaysia, The ruling on the use of surrogate mother to have a child, Fatwa Management Division, 10 July 2008, retrieved 16 April 2015,

$<$ http://www.e-fatwa.gov.my/fatwa-negeri/hukum-menggunakan-kaedah-khidmat-ibu-tumpang-untukmendapatkan-zuriat>.

[7] Department of Islamic Development Malaysia, What is Fatwa?, Fatwa Management Division, 2015, retrieved 16 April 2015,

$<$ http://www.e-fatwa.gov.my/apa-itu-fatwa $>$.

[8] Government of Selangor, Hukum Menggunakan Kaedah Khidmat Ibu Tumpang (Surrogate Motherhood) Untuk Mendapatkan Zuriat, Gazette No. 1, Reference No. MAIS/SU/BUU/02/016/2-1; P.U. Sel. AGM. 0007. Jld. 2, 6 February 2011, retrieved 17 April 2015,

$<$ http://jawatankuasafatwakumpulan7tlc4.yolasite.com/resources/PewartaanFatwa2011(3).p $>$.

[9] KH Win@ MH Ahmed, 'Law: Functions, Classifications and Divisions', in AAA Mohamad (ed.), Malaysian Legal System, The Malaysian Current Law Journal Sdn Bhd, 2014.

[10] WA Hamzah, A First Look at the Malaysian Legal System, Oxford Fajar Sdn Bhd, 2009

[11] WM Aun, The Malaysian Legal System, 3rd edn, Pearson Malaysia Sdn Bhd, 2005. 